\title{
STUDI ANGKA KUMAN UDARA PUSKESMAS KABUPATEN BANYUMAS
}

\author{
Fitri Setyaningsih" ${ }^{1)}$, Tri Cahyono ${ }^{2}$ \\ Poltekkes Kemenkes Semarang, Poltekkes Kemenkes Semarang
}

\begin{abstract}
Abstrak
Pusat kesehatan masyarakat atau puskesmas merupakan fasilitas pelayanan kesehatan yang menyelenggarakan upaya kesehatan masyarakat dan upaya kesehatan perseorangan tingkat pertama, dengan lebih mengutamakan upaya promontif dan preventif, untuk mencapai derajat kesehatan masyarakat yang setinggi-tingginya di wilayah kerjanya. Tujuan penelitian ini adalah megukur parameter fisik udara (suhu,kelembapan, pencahayaan), mendeskripsikan sarana sanitasi dan sarana prasarana bangunan , mendeskripsikan aktifitas pada Ruangan, dan mengukur jumlah angka kuman udara. Penelitian ini dilakukan dengan metode deskriptif observasional yang bertujuan untuk mengetahui jumlah kuman pada Ruangan di Puskesmas I Purwokerto Utara. Hasil penelitian menunjukan bahwa parameter suhu udara di Puskesmas 1 Purwokerto utara pada Ruang Poli gigi, Poli Lansia, Pemeriksaan Umum, Gizi dan MTBS masih ada yang belum memenuhi Syarat. rata-rata suhu ruangan $28^{\circ} \mathrm{C}$, Kelembapan rata-rata $45,75 \%$, Pencahayaan rata-rata $867,5 \mathrm{Lux}$, dan angka kuman udara rata-rata285.555 CFU $/ \mathrm{m}^{3}$. Sarana sanitasi yang terdapat pada ruangan seperti lantai, dinding, langit-langit, Ac. Penelitian menyimpulkan Kondisi fisik lingkungan berupa suhu, kelembapan, pencahayaan, belum memenuhi syarat. Peneliti menyarankan untuk melakukan pemeriksaan angka kuman udara secara berkala dan melakukan pengendalian angka kuman udara menggunakan alat UV countinue serta pelaksaan pengepelan (dusting) dengan menngunakan desinfektan yang intensif.
\end{abstract}

Kata kunci : Angka Kuman; udara; Kesehatan Lingkungan

\begin{abstract}
A public health center or health center is a health service facility that carries out public health efforts and individual health efforts of the first level, with priority on Promotional and preventive efforts, to achieve the highest degree of public health in its working area. The purpose of this research is Megukur physical parameters of air (temperature, humidity, lighting), Describe sanitation facilities and building infrastructure, Describe the activities on the room, and Measure the number of air germ figures.This research was conducted by descriptive observational method that aims to know the number of germs in the room at Puskesmas I Purwokerto Utara.The result of the research shows that the temperature parameters at Puskesmas 1 Purwokerto north on Dental Poly Room, Elderly Police, General Examination, Nutrition and MTBS still have not fulfill the requirement. average room temperature $28^{\circ} \mathrm{C}$, average humidity $45.75 \%$, average illumination $867,5 \mathrm{Lux}$, and average air gap rate $285.555 \mathrm{CFU} / \mathrm{m}^{3}$. Sanitary facilities in rooms such as floors, walls, ceilings, ac.The study concluded that the physical condition of the environment in the form of temperature, humidity of lighting, not yet qualified. Researchers recommend to check the airborne germ period regularly and control the number of airborne bacteria using UV countinue and dusting by using intensive disinfectant.
\end{abstract}

Keywords : The germ; Air; Environmental Health

1) Email : Fitrisetiyaningsih4@gmail.com

2) Email : tricahyono37@yahoo.co.id 


\section{PENDAHULUAN}

Kesehatan Lingkungan adalah upaya pencegahan penyakit atau gangguan kesehatan dari faktor resiko lingkungan untuk mewujudkan kualitas lingkungan yang sehat baik dari aspek fisik,kimia,biologi maupun sosial (PP No.66/2014, Pasal 1 butir 1). Bidang ilmu kesehatan lingkungan merupakan ilmu yang mengkaji tentang penyehatan air dan limbah cair,penyehatan udara, penyehatan tanah dan pengelolaan sampah, penyehatan makan dan minuman, penyehatan sarana dan bangunan, dan pengendalian vektor dan binatang pembawa penyakit, keenam kajian tersebut diaplikasikan dalam lingkunagan permukiman, tempat kerja, tempat rekreasi,tempat dan fasilitas umum.

Tempat-Tempat Umum adalah suatu tempat dimana orang banyak berkumpul untuk melakukan kegiatan baik secara insidental maupun terus menerus. Yang termasuk dalam kategori tempat-tempat umum dimana orang banyak melakukan kegiatan diantaranya : Pasar, Gedung Bioskop, Restoran , Masjid, Mall, supermarket, Bandara, Stasiun, Rumah Sakit, Puskesmas. (Suparlan, 1981, h.4)

Puskesmas yang baik harus memenuhi persyaratan atau sarana prasarana yang memadai dan juga jenis layanannya. Kondisi fisik meliputi Sanitasi gedung, udara, air . Dengan adanya sanitasi udara di harapkan angka kuman menjadi rendah, dengan rendahnya angka kuman, maka infeksi nosokomial bisa di cegah. Indeks angka kuman udara yang tidak sesuai ketentuan dalam Kemenkes RI Nomor 1204/MENKES/SK/X/2004 dapat menyebabkan infeksi

nosokomial/Heathcare Associated

Infections (HAIs). Infeksi Nosokomial banyak terjadi di seluruh dunia dengankejadian terbanyak terbanyak di negara miskin dan negara yang sedang berkembang , karena penyakit-penyakit infeksi masih menjadi penyebab utamanya.

Puskesmas adalah suatu tempat yang digunakan untuk menyelenggarakan upaya pelayanan kesehatan yang digunakan untuk menyelenggarakan upaya pelayanan kesehatan, baik promotif, preventif, kuratif maupun rehabilitatif yang dilakukan oleh pemerintah,pemerintah daerah dan/atau masyarakat (Permenkes RI Nomor 75 Tahun 2014).
Tujuan penelitian ini adalah untuk mengetahui angka kuman udara, megukur kualitas fisik udara (suhu,kelembapan, pencahayaan), mendeskripsikan sarana sanitasi dan sarana prasarana bangunan , mendeskripsikan aktifitas pada ruangan, menghitung jumlah angka kuman udara pada ruangan.

\section{BAHAN DAN METODE PENELITIAN}

Design Identifikasi yang dilakukan yaitu penelitian deskriptif observasional yang bertujuan untuk mengetahui jumlah angka kuman pada Ruangan di Puskesmas I Purwokerto Utara.

Subjek penelitian ini adalah angka kuman udara Ruangan di Puskesmas I Purwokerto Utara . Pengambilan sampel dilakukan pada 1 titik untuk sampel angka kuman udara yang di lakukan selama 1 hari dan juga melakukan pengukuran parameter fisik ruang pemeriksaan umum, ruang poli lansia, ruang MTBS dan gizi, ruang gigi dan mulut di Puskemas I Purwokerto Utara, yaitu suhu, kelembapan, pencahayaan, ventilasi.

Jenis data yang digunakanyaitu data umumdan data khusus. Data umum meliputi Gambaran umum mengenai Puskesmas I Purwokerto Utara berupa struktur organisasi, jumlah pasien dan batas wilayah geografis. Data khusus meliputi Hasil Penilaian dari pegukuran suhu, kelembapan, pencahayaan, ventilasi, sanitasi ruangan dan jumlah angka kuman yang ada Pada Ruangan di Puskesmas I Purwokerto Utara .

Sumber data dari penelitian ini adalah data primer dan data sekunder.Data Primer diperoleh dari hasil observasional, wawancara dan pengukuran suhu, kelembapan, pencahayaan, ventilasi, dan jumlah angka kuman udara ruangan di Puskesmas I Purwokerto Utara. Data Sekunder di Peroleh Dari Kantor Dinas Kesehatan dan Puskesmas I Purwokerto Utara.

Analisis data yang di gunakan dalam penelitian ini adalah dengan menganalisis semua data yang telah diolah dan kemudian dibandingkan dengan Keputusan Menteri Kesehatan Republik Indonesia Nomor 1204/MENKES/SK/X/2004 tentang Persyaratan Kesehatan Lingkungan Rumah Sakit dan Keputusan Menteri Kesehatan Republik Indonesia Nomor 
1428/MENKES/SK/XII/2006 tentang

Kesehatan Lingkungan Puskesmas.

\section{HASIL DAN PEMBAHASAN}

A. Puskesmas 1 Purwokerto Utara

Puskesmas I Purwokerto Utara terletak di Jalan Beringin, Bancarkembar, Purwokerto Utara, Kabupaten Banyumas, Jawa Tengah 53121 memiliki luas wilayah 4,41 $\mathrm{km}^{2}$.Pada tanggal 3 Februari 1989 Puskesmas mulaidikembangkan, Puskesmas I Purwokerto Utara telah Mendapatkan Gelar Madya pada tahun 2017.

Pelayanan Kesehatan di Puskesmas I Purwokerto Utara terdiri dari Jenis pelayanan Ruang pemeriksaan Umum, Pelayanan Kesehatan Gigi dan Mulut, Pelayanan KIA, Pelayanan KB, Pelayanan MTBS, Pelayanan Imunisasi, Ruang Gawat Darurat, Pelayanan Gizi, Pelayanan Kefarmasian, Pelayanan Laboratorium, Pelayanan Prolanis, Konseling Sanitasi, pelayanan Keperawatan, Kesehatan Masyarakat dan Pelayanan Puskesmas Keliling.

B. Ruangan di Puskesmas 1 Purwokerto Utara

1. Hasil Kondisi Lingkungan Fisik Ruangan

a. Suhu

\begin{tabular}{|c|c|c|c|c|}
\hline No & Tanggal & Lokasi & $\begin{array}{l}\text { Hasil } \\
\left({ }^{0} \mathrm{C}\right) \\
\end{array}$ & $\begin{array}{l}\text { Standar } \\
\left({ }^{\circ} \mathrm{C}\right)\end{array}$ \\
\hline 1. & $26 / 02 / 2018$ & R. Poli Gigi & 28 & $22-24$ \\
\hline 2. & $26 / 02 / 2018$ & R. Poli Lansia & 29 & $22-24$ \\
\hline 3. & $26 / 02 / 2018$ & $\begin{array}{l}\text { R.Pemeriksaan } \\
\text { Umum }\end{array}$ & 28 & $22-24$ \\
\hline 4. & $26 / 02 / 2018$ & Gizi dan MTBS & 27 & $22-24$ \\
\hline \multicolumn{3}{|c|}{ Rata-Rata } & 28 & \\
\hline
\end{tabular}

Pengukuran suhu diPuskesmas I Purwokerto Utara di lakukan pengukuran selama dalam 1 hari, yaitu pada hari senin 26 Februari 2018 pukul 10.00 WIB di ruang Poli Gigi dapatkan hasil sebesar $28^{\circ} \mathrm{C}$, Pada ruang Poli Lansia di ambil pengukuran suhu pada pukul 11.07 WIB di dapatkan hasil sebesar $\quad 29^{\circ} \mathrm{C}$, Pada ruang Pemeriksaan Umum di ambil pengukuran suhu pada pukul 11.25 WIB di dapatkan hasil sebesar $28^{\circ} \mathrm{C}$, Pada ruang Gizi dan MTBS di lakukanpengukuran pada pukul 11.45 WIB di dapatkan hasil sebsar $27^{0} \mathrm{C}$.
Berdasarkan hasil pengukuran suhu di ruang Poli Gigi, Poli Lansia, Pemeriksaan Umum, Gizi dan MTBS menunjukan bahwa suhu ruangan tidak memenuhi syarat menurut Kepmenkes RI Nomor 1204/MENKES/SK/X/2004.

Berdasarkan Klasifikasi pertumbuhan bakteri terhadap suhu maka bakteri yang tumbuh di ruangan Poli Gigi, Poli Lansia, Pemeriksaan Umum, Gizi dan MTBS Puskesmas I Purwokerto Utara adalah jenis mikroba psikofil dan mesofil.

Suhu ruanganan di puskesmas harus memenuhi syarat sesuai dengan Keputusan Menteri Kesehatan Republlik Indonesia Nomor 1204/MENKES/SK/X/2004 tentang Persyaratan Kesehatan Lingkungan, sehingga upaya penanganan suhu ruangan agar Memenuhi Syarat dapat dilakukan dengan melakukan perawatan pada AC secara berkala serta memberi Termohgrometer pada ruangan yang telah diberi keterangan Standar Suhu dan Kelembapan ruangan.

b. Kelembapan

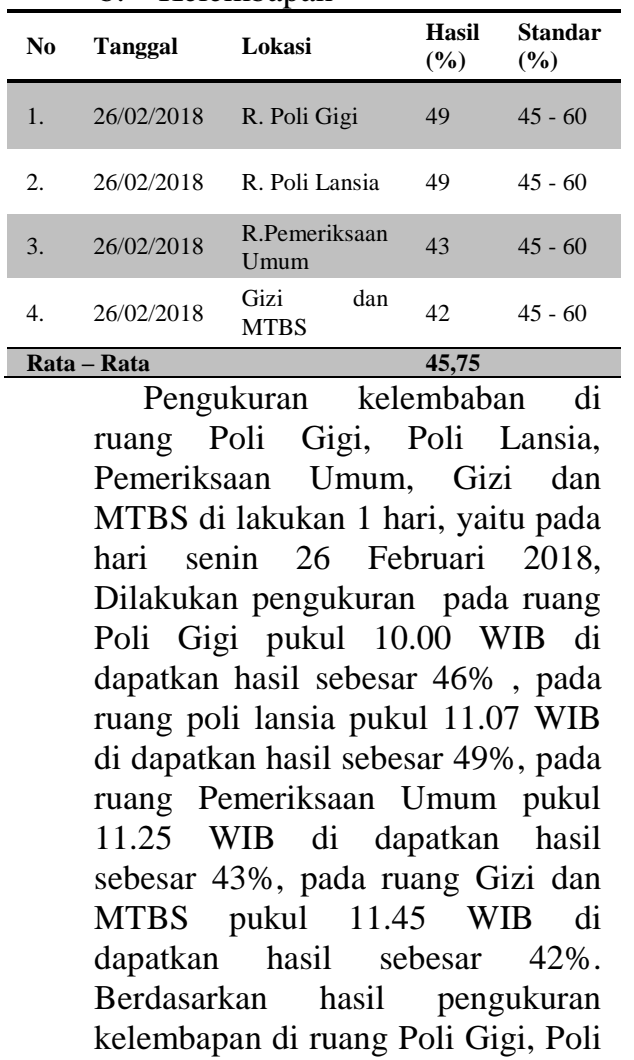


Lansia, Pemeriksaan Umum, Gizi dan MTBS Puskesmas I Purwokerto Utara Masih ada Beberapa yang belum Memenuhi Syarat yaitu di ruang Pemeriksan Umum, Gizi dan MTBS. Kelembapan ruanganan di puskesmas harus Memenuhi Syarat sesuai dengan Keputusan Menteri Kesehatan Republlik Indonesia Nomor1204/MENKES/SK/X/2004

tentang Persyaratan Kesehatan Lingkungan, sehingga upaya penanganan suhu ruangan agar Memenuhi Syarat dapat dilakukan dengan melakukan perawatan pada AC, di tambahkan pemasangan alat Humidifier di setiap ruangan untuk menambahkan jumlah uap air di udara ruangan serta memberi Termohgrometer pada ruangan yang telah diberi keterangan Standar Suhu dan Kelembapan.

c. Pencahayaan

\begin{tabular}{|c|c|c|c|}
\hline No & Tanggal & Lokasi & $\begin{array}{c}\begin{array}{c}\text { Standar } \\
\text { (Lux) }\end{array} \\
\text { (Lux }\end{array}$ \\
\hline 1. & $26 / 02 / 2018$ & R. Poli Gigi & $\begin{array}{c}100- \\
200\end{array}$ \\
\hline 2. & $26 / 02 / 2018$ & R. Poli Lansia & $\begin{array}{c}100- \\
200\end{array}$ \\
\hline 3. & $26 / 02 / 2018$ & $\begin{array}{l}\text { R.Pemeriksaan } \\
\text { Umum }\end{array}$ & $\begin{array}{l}100- \\
200\end{array}$ \\
\hline 4. & $26 / 02 / 2018$ & $\begin{array}{l}\text { Gizi dan } \\
\text { MTBS }\end{array}$ & $\begin{array}{c}100- \\
200\end{array}$ \\
\hline \multicolumn{3}{|c|}{ Rata-Rata } & 867,5 \\
\hline & $\begin{array}{l}\text { Per } \\
\text { rua } \\
\text { Per } \\
\text { MT } \\
\text { Pur } \\
\text { sela } \\
\text { sen } \\
\text { Dil } \\
\text { rua } \\
\text { WI } \\
\text { 346 } \\
\text { lan } \\
\text { dap } \\
\text { Lu> } \\
\text { Um } \\
\text { dap } \\
\text { Lu> } \\
\text { MT } \\
\text { dap } \\
\text { Lu> } \\
\text { pen } \\
\text { rua } \\
\text { Per } \\
\text { MT }\end{array}$ & $\begin{array}{l}\text { Jukuranpenc } \\
\text { g Poli Gigi } \\
\text { eriksaan Un } \\
\text { 3S Pus } \\
\text { vokerto Ut } \\
\text { na I hari, y } \\
26 \\
\text { kukan peng } \\
\text { g Poli Gig } \\
\text { di dapatka } \\
\text { Lux pas } \\
\text { a pukul } 1 \\
\text { tkan hasil } \\
\text { pada ruan } \\
\text { Im pukul } 1 \\
\text { tkan hasil } \\
\text { pada rua } \\
\text { 3S pukul } 1 \\
\text { tkan hasil } \\
\text { Berdas } \\
\text { ukuran pe } \\
\text { Poli Gigi } \\
\text { eriksaan Un } \\
\text { 3S Tidak Me }\end{array}$ & $\begin{array}{l}\text { hayaan di } \\
\text { Poli Lansia, } \\
\text { um, Gizi dan } \\
\text { esmas } \\
\text { ra dilakukan } \\
\text { itu pada hari } \\
\text { oruari } 2018 \\
\text { kuran pada } \\
\text { pukul } 10.00 \\
\text { hasil sebesar } \\
\text { ruang poli } \\
.07 \text { WIB di } \\
\text { sebesar } 1486 \\
\text { Pemeriksaan } \\
\text { l.25 WIB di } \\
\text { sebesar } 1254 \\
\text { g Gizi dan } \\
\text { l.45 WIB di } \\
\text { sebesar } 384 \\
\text { rkan hasil } \\
\text { cahayaan di } \\
\text { Poli Lansia, } \\
\text { um, Gizi dan } \\
\text { menuhi Syarat }\end{array}$ \\
\hline
\end{tabular}

Menurut Kepmenkes RI Nomor 1204/MENKES/SK/SK/X/2004 tentang Persyaratan Kesehatan Lingkungan. Upaya penanganan pencahayaan ruanagan agar Memenuhi Syarat dapat di lakukan dengan menambahkan daya lampu di ruang Poli Gigi, Poli Lansia, Pemeriksaan Umum, Gizi dan MTBS agar pencahayaan dalam ruangan dapat meningkat dan bisa sesuai dengan ketentuan Persyaratan Kepmenkes RI Nomor 1204/MENKES/SK/X/2004 tentang Persyaratan Kesehatan Lingkungan.

d. Ventilasi

\begin{tabular}{cclcc}
\hline No & Tanggal & Lokasi & $\begin{array}{c}\text { Hasil } \\
(\mathbf{\%})\end{array}$ & $\begin{array}{c}\text { Standar } \\
(\mathbf{\%})\end{array}$ \\
\hline 1. & $26 / 02 / 2018$ & R. Poli Gigi & 13,08 & 15 \\
\hline 2. & $26 / 02 / 2018$ & $\begin{array}{l}\text { R. Poli } \\
\text { Lansia } \\
\text { R.Pemerisaan } \\
\text { Umum }\end{array}$ & 12,47 & 15 \\
\hline 3. & $26 / 02 / 2018$ & $\begin{array}{l}\text { Gizi dan } \\
\text { MTBS }\end{array}$ & 15,18 & 15 \\
\hline 4. & $26 / 02 / 2018$ & & 15 \\
\hline
\end{tabular}

Rata - Rata

Pengkuran luas ventilasi di ruang Poli Gigi, Poli Lansia, Pemeriksan Umum Puskesmas I Purwokerto utara dilakukan selama 1 hari, yaitu pada hari senin 26 Februari 2018 di ruang Poli Gigi pukul 10.00 WIB di dapatkan hasil untuk luas ventilasi sebesar 13,082\% , pada ruang Poli Lansia pukul 11.07 WIB di dapatkan hasil untuk luas ventilasi sebesar $25,687 \%$, pada ruang Pemeriksaan Umum pukul 11.25 WIB di dapatkan hasil untuk luas ventilasi sebesar $12,479 \%$, pada ruang Gizi dan MTBS pukul 11.45 WIB di dapatkan hasil untuk luas lantai sebesar 15,184\%. Berdasarkan hasil pengukuran di ruang Poli Lansia, Gizi dan MTBS Puskesmas I Purwokerto Utara menunjukan luas ventilasi ruangan telah Memenuhi Syarat menurut Kepmenkes RI Nomor 1204/MENKES/SK/X/2004 


\begin{abstract}
Tentang Kesehatan Lingkungan. Dan pada ruang Poli Lansia dan ruang Pemeriksaan Umum Puskesmas I Purwokerto Utara Belum Memenuhi Syarat menurut Kepmenkes RI Nomor 1204/MENKES/SK/X/2004

Tentang Kesehatan Lingkungan.
\end{abstract}

2. Penilaian Sarana Sanitasi dan Sarana Prasarana Ruangan.

\begin{tabular}{|c|c|c|c|c|c|}
\hline No & Item & $\begin{array}{l}\text { R. } \\
\text { Gigi }\end{array}$ & $\begin{array}{c}\mathbf{R .} \\
\text { Lansia }\end{array}$ & $\begin{array}{l}\text { R.Pemeriksaan } \\
\text { Umum }\end{array}$ & $\begin{array}{c}\text { R. } \\
\text { Gizi } \\
\text { dan } \\
\text { MTBS }\end{array}$ \\
\hline 1. & Lantai & 180 & 180 & 180 & 180 \\
\hline 2. & Dinding & 100 & 100 & 100 & 100 \\
\hline 3. & Ventilasi & 50 & 50 & 50 & 50 \\
\hline 4. & Atap & 50 & 50 & 50 & 50 \\
\hline 5. & $\begin{array}{l}\text { Langit- } \\
\text { Langit }\end{array}$ & 50 & 50 & 50 & 50 \\
\hline 6. & Pintu & 50 & 50 & 50 & 50 \\
\hline 7. & $\begin{array}{l}\text { Ruang } \\
\text { Puskesmas }\end{array}$ & 50 & 50 & 40 & 40 \\
\hline \multicolumn{2}{|r|}{ Jumlah } & $81,5 \%$ & $81,5 \%$ & $80 \%$ & $80 \%$ \\
\hline
\end{tabular}

sanitasi ruangan pagi hari senin 26 Februari 2018 dalam keadaan ruangan tidak sedang di lakukan kegiatan pembersihan ruangan terkait sarana sanitasi ruangan seperti lantai, dinding dan langitlangit. Kemudian kondisi di ruang Poli Gigi, Gizi dan MTBS dalam keadaan tertutup, pada ruang Poli Lansia dan Pemeriksaan Umum dalam keadaan terbuka, serta keadaan jendela dan ventilasi dalam keadaan tertutup rapat oleh kaca, kemudian kondisi seluruh AC pada saat itu dalam keadaan menyala "ON". dan Pembersihan setiap ruanagan di lakukan sebelum pasien datang (Pagi hari) dan sesudah pasien pulang (Sore hari), petugas kebersihan berjumlah satu orang dan melakukan pembersihan setiap ruangan \pm 1 jam.

a. Ruang Poli Gigi

Dari tabel tersebut,ruang Poli

Gigi Puskesmas I Purwokerto Utara belum memenuhi syarat dengan hasil sebesar73,684\%. Menurut Keputusan KeputusanMenteri Kesehatan Republik Indonesia Nomor 1204/MENKES/SK/X/2004

Tentang Kesehatan Lingkungan dikatakan memenuhi syarat jika memperoleh hasil sebesar $81,5 \%$, sebaiknya di lakukan penambahan Ventilasi alami pengecekan AC secara berkala, pembersihan ruangan panda lantai, dinding, dan langit langit secara berkala.

b. Ruang Poli Lansia

Dari tabel tersebut, Poli

Lansia Puskesmas I

Purwokerto Utara Utara di dapatkan hasil 93,567\%.

Menurut Keputusan

KeputusanMenteri Kesehatan

Republik Indonesia Nomor 1204/MENKES/SK/X/2004

Tentang Kesehatan

Lingkungan dikatakan

memenuhi syarat jika

memperoleh hasil sebesar

$81,5 \%$,sebaiknya dilakukan penambahan Ventilasi alami dan pengecekan AC secara berkala.

c. Ruang Pemeriksaan Umum

Dari tabel tersebut, ruang

Pemeriksaan Umum Puskesmas I Purwokerto Utaradi dapatkan hasil $74,853 \%$.

Menurut Keputusan

KeputusanMenteri Kesehatan Republik Indonesia Nomor 1204/MENKES/SK/X/2004

Tentang Kesehatan Lingkungan dikatakan memenuhi syarat jika memperoleh hasil sebesar $80 \%$, sebaiknya dilakukan penambahan Ventilasi alami dan pengecekan AC secara berkala, pembersihan ruangan panda lantai, dinding, dan langit - langit secara berkala.

d. Ruang Gigi dan MTBS

Dari tabel tersebut, ruang Pemeriksaan Umum Puskesmas I Purwokerto Utaradi dapatkan hasil $80,70 \%$.

Menurut Keputusan KeputusanMenteri Kesehatan Republik Indonesia Nomor 1204/MENKES/SK/X/2004

Tentang Kesehatan Lingkungan dikatakan memenuhi syarat 
jika memperoleh hasil sebesar $80 \%$,

3. Kondisi Aktivitas Ruangan

Gambaran kondisi aktivitas kondisi ruangan yaitu 2 orang petugas puskesmas yang terdiri dari 1 Dokter , 1 perawat, Kemudian aktivitas ruangan juga di pengaruhi tim penelitian dengan total 4 orang tim penelitian yang terdiri dari 1 orang operator impinger, 1 orang penelitian dan 2 orang dokumentasi pemeniltian dan pada saat melakukan penelitian terdapat 1 pasien yang akan melakukan pemeriksan Gigi. Pada Ruang Poli Lansia terdapat 1 orang Dokter Kemudian aktivitas ruangan juga di pengaruhi tim penelitian dengan total 4 orang tim penelitian yang terdiri dari 1 orang operator impinger, 1 orang penelitian dan 2 orang dokumentasi pemeniltian, namun pada saat itu tidak terdapat terdapat pasien yang mendapat penanganan medis di ruang Poli Lansia. Pada ruang Pemeriksaan Umum terdapat 3 Orang dokter, Kemudian aktivitas ruangan juga di pengaruhi tim penelitian dengan total 4 orang tim penelitian yang terdiri dari 1 orang operator impinger, 1 orang penelitian dan 2 orang dokumentasi pemeniltian, pada saat melakukan penelitian terdapat 3 pasien yang akan melakukan pemeriksan Kesehatan. Pada ruang Gizi dan MTBS terdapat 2 orang yang terdiri dari 1 orang petugas gizi dan 1 orang perawat. Kemudian aktivitas ruangan juga di pengaruhi tim penelitian dengan total 4 orang tim penelitian yang terdiri dari 1 orang operator impinger, 1 orang penelitian dan 2 orang dokumentasi pemeniltian.

4. Hasil Pengukuran Angka Kuman Udara

\begin{tabular}{cclcc}
\hline No & Tanggal & \multicolumn{1}{c}{ Lokasi } & $\begin{array}{c}\text { Hasil } \\
\left(\mathrm{CFU} / \mathrm{m}^{3}\right)\end{array}$ & $\begin{array}{c}\text { Standar } \\
\left(\mathrm{CFU} / \mathrm{m}^{3}\right)\end{array}$ \\
\hline 1. & $26 / 02 / 2018$ & R. Poli Gigi & 437.777 & $\begin{array}{c}200- \\
500\end{array}$ \\
2. & $26 / 02 / 2018$ & R. Poli Lansia & 337.779 & $\begin{array}{c}200- \\
500\end{array}$ \\
& \multirow{2}{*}{$26 / 02 / 2018$} & $\begin{array}{l}\text { R.Pemeriksaan } \\
\text { Umum }\end{array}$ & 365.333 & $\begin{array}{c}200- \\
500\end{array}$
\end{tabular}

$\begin{array}{llcc}\text { 4. } 26 / 02 / 2018 & \text { Gizi dan MTBS } & 1.333 & 200- \\ 500\end{array}$

Pada ruang Poli Gigi di lakukan pengukuran pukul 10.00 WIB, di dapatkan hasil sebesar 437.777 $\mathrm{CFU} / \mathrm{m}^{3}$. Pada ruang Poli Lansia di lakukan pengukuran pukul 11.07 WIB, di dapatkan hasil sebesar $337.779 \mathrm{CFU} / \mathrm{m}^{3}$. Pada ruang Pemeriksan Umum di lakukan pengukuran pukul 11.25 WIB, di dapatkan hasil sebesar 365.333 $\mathrm{CFU} / \mathrm{m}^{3}$. Pada ruang Gizi dan MTBS di lakukan pengukuran pukul 11.45 WIB, di dapatkan hasil sebesar 1.333 CFU/m³.

Persyartan Kualitas udara ruangan yang di tetapkan oleh Kementerian Kesehatan maksimal $500 \mathrm{CFU} / \mathrm{m}^{3}$,sehingga pada ruangan Puskesmas masih belum memenuhi syaratdan berdasarkan data penyakit berbasis lingkungan pada tahun 2017 di Puskesmas I purwokerto utara yaitu di terdapat pasien yang terindikasiTb Paru, penyakit kulit, influenza.

Menurut Tri Cahyono (2017)

Gejalapenyakit yang di akibatkanolehudarayaitu 1) pneumonia yang di sebabkanolehinfeksiakutpadaparuparuyaituterjadinyaperadanganpada selaputpembungkusparu-paru

(pleura), 2) Difteri yang di sebabkan oleh bakteri corynebacteriumdiptherial, yang dapat menimbulkan penyumbatan pada rongga faring atau laring oleh lender yang yang dihasilkna olehbakteritersebut, 3) Tubercolosis (TBC) yaitu penyakit bakterial yang bersifatkronis, dan disebabkanoleh mycobacterium tuberculosis. 4) Meningitis yaitu infeksi bacterialakut yang di sebabkan meningitis (bakteri gram aktif)5) Influenza yaitu penyakit saluran pernafasan yang di sebabkanoleh virus influenza. 6) Cacaryaitu di sebabakanoleh virus varicella zozter. kemudian di Puskesmas I purwokerto Utara tidak ada pengendalian angka kuman udara ruang sehigga 
ruangan Puskesmas di dapatkan hasil yang tinggi, Puskesmas I Purwokerto Utara Juga belum pernah di lakukannya pengendalian angka kuman sehingga dapat mempengaruhi banyaknya angka kuman udara ruangan.

\section{PENUTUP}

Hasil Penelitian mengenai angka kuman udara di ruang Poli Gigi, Poli Lansia, Pemeriksaan Umum, Gizi dan MTBS Puskesmas I Purwokerto Utara menyimpulkan bahwa :

1. Kondisi Fisik Lingkungan di ruang Poli Gigi, Poli Lansia, Pemeriksaan Umum, Gizi dan MTBS.

a. Suhu pada ruang Poli Gigi sebesar $28^{\circ} \mathrm{C}$, pada ruang Poli Lansia sebesar $29^{\circ} \mathrm{C}$. pada ruang Pemeriksaan Umum sebesar $28^{\circ} \mathrm{C}$, pada ruang Gizi dan MTBS sebesar $27^{\circ} \mathrm{C}$ dengan rata - rata $28^{0} \mathrm{C}$.

b. Kelembapan pada ruang Poli Gigi sebesar 46\%, pada ruang Poli Lansia sebesar $49 \%$. pada ruang Pemeriksaan Umum sebesar $43 \%$, pada ruang Gizi dan MTBS sebesar $42 \%$ dengan rata - rata $45,75 \%$.

c. Pencahayaan pada ruang Poli Gigi sebesar 346Lux, pada ruang Poli Lansia sebesar 1486 Lux, pada ruang Pemeriksaan Umum sebesar 1254 Lux, pada ruang Gizi dan MTBS sebesar 384 Lux dengan rata - rata 867,5 Lux.

2. Sarana sanitasi pada ruang Poli Gigi sebesar 81,5\%, ruang Poli Lansia sebesar $81,5 \% \%$, ruang Pemeriksaan Umum sebesar $80 \%$, ruang Gizi dan MTBS sebesar $80 \%$.Seluruh Sarana dan Prasarana yang tersedia di ruang Gigi, Poli Lansia, Pemeriksaan Umum, Gizi dan MTBS, selalu di lakukan pembersihan dan perawatan secara berkala.

3. Aktivitas Ruangan di Puskesmas 1 Purwokerto Utara Selalu ada kegiatan pemeriksaan kesehatan.

4. Angka kuman udara di ruang Poli Gigi sebesar 437.777 $\mathrm{CFU} / \mathrm{m}^{3}$. Pada ruang Poli Lansia sebesar $337.777 \mathrm{CFU} / \mathrm{m}^{3}$, Pada ruang Pemeriksaan Umum sebesar
365.333 $\mathrm{CFU} / \mathrm{m}^{3}$. Pada ruang Gizi dan MTBS sebesar $1.333 \mathrm{CFU} / \mathrm{m}^{3}$, dengan rata- rata $285.555 \mathrm{CFU} / \mathrm{m}^{3}$ dan ruangan puskesmas tidak memenuhi syarat.

\section{DAFTAR PUSTAKA}

Handika Rizki Nugraha. 2016.Studi Angka Kuman Udara di Ruang Operasi Rumah Sakit Wijaya Kusuma Purwokerto. Purwokerto: Politeknik Kesehatan Kementrian Kesehatan Semarang Jurusan Kesehatan Lingkungan.

Jefri Setiawan. 2017.Studi Angka Kuman Udara di Ruang Instalasi Gawat Darurat (IGD) Rumah Sakit PKU Muhammadiyah Gombong Kabupaten Kebumen. Purwokerto : Politeknik Kesehatan Kementrian Kesehatan Semarang Jurusan Kesehatan Lingkungan.

Republik Indonesia. 1980. Keputusan Menteri Kesehatan Nomor 4 Tahun 1980 tentang Syarat - syarat Pemasangan Alat Pemadam Api Ringan ( APAR). Sekretariat Jenderal Departemen Kesehatan, Jakarta.

2014. Keputusan Menteri Kesehatan Nomor 66 Tahun 2014 tentang Kesehatan Lingkungan. Sekretariat Jenderal Kementerian Kesehatan, Jakarta.

2013. Keputusan Menteri Kesehatan Nomor 71 Tahun 2013 tentang Pelayanan Kesehatan pada Jaminan Kesehatan Nasional.Sekretariat Jenderal Kementerian Kesehatan, Jakarta.

2014. Keputusan Menteri Kesehatan Nomor 75 Tahun 2014 tentang Pusat Kesehatan Masyarakat.Sekretariat Jenderal Kementerian Kesehatan, Jakarta.

2004. Keputusan Menteri Kesehatan 1204/MENKES/SK/X/2004 tentang Persyaratan Lingkungan Rumah Sakit.Sekretariat Jenderal Departemen Kesehatan, Jakarta. 


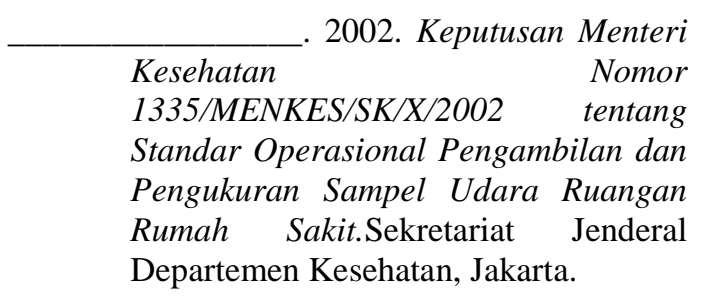

$\begin{array}{lrr} & 2006 . & \text { Keputusan } \\ \text { Menteri } & \text { Kesehatan } & \text { Nomor } \\ \text { 1428/MENKES/SK/XII/2006 } & \text { tentang } \\ \text { Pedoman Penyelenggaraan } & \text { Kesehatan } \\ \text { Lingkungan Puskesmas. } & \text { Sekretariat } \\ \text { Jenderal Departemen } & \text { Kesehatan, } \\ \text { Jakarta. } & & \end{array}$
2009. Undang-Undang Republik Indonesia Nomor 44 Tahun 2009 tentang Rumah Sakit. Menteri Hukum dan Hak Asasi Manusia, Jakarta.

2004. Undang-Undang Republik Indonesia Nomor 36 Tahun 2004 tentang Kesehatan.Menteri Hukum dan Hak Asasi Manusia, Jakarta.

Restuti Ayu Waluyo. 2016.Efektifitas Sterilisasi Menggunakan Ultraviolet (UV) pada Ruang Perawatan Rumah Sakit Umum Daerah Banyumas. Purwokerto : Politeknik Kesehatan Kementrian Kesehatan Semarang Jurusan Kesehatan Lingkungan.

Suharsimi Arikunto. 1998.Prosedur Penelitian Suatu Pendekatan Praktek, Edisi revisi IV, Jakarta: Rineka Cipta.

Suparlan. 1981.Pedoman Pengawasan Sanitasi Tempat - tempat Umum, Jakarta: Akademi Penilik Kesehatan Teknologi Sanitasi.

Tri Cahyono. 2017. Penyehatan Udara. Yogyakarta : Penerbit ANDI (Anggota IKAPI).

Tri Cahyono. 2017.Panduan Penulisan Tugas Akhir, Purwokerto : Politeknik Kesehatan Kementerian Kesehatan Semarang Jurusan Kesehatan Lingkungan. www.google.co.id/amp/s/kbbi.web.id/udara.htm ldiakses pada tanggal 12 November 2017 pada pukul 14:00

www.google.co.id/search?q=termometer\&client $=$ ms-android$\underline{\text { samsung\&source }=\text { android- }}$ $\underline{\text { browser \&dcr }=0 \& \text { prmd }=\mathrm{ibn} v \& \text { source }=1}$ $\underline{\text { nms\&tbm }=i s c h \& s a=X \& v e d=0 a h U K E}$ wjrjZXZqbvYAhVLv48KHYLtAjUQ $\underline{\text { AUICSgB\&biw=360\&bih=616\#imgrc }=}$ oAYWhjv6LOOgmM\%3A diakses pada tanggal 20 Desember 2017 pada pukul 14:05 